\title{
Paideusis
}

\section{Embodied Wisdom: Meditations on Memoir and Education (Alison Pryer)}

\section{Barbara Bickel}

Volume 20, Number 2, 2012

Contemplative Practice, Education, and Socio-Political

Transformation (Part One)

URI: https://id.erudit.org/iderudit/1071831ar

DOI: https://doi.org/10.7202/1071831ar

See table of contents

Publisher(s)

Canadian Philosophy of Education Society

ISSN

0838-4517 (print)

1916-0348 (digital)

Explore this journal

Cite this review

Bickel, B. (2012). Review of [Embodied Wisdom: Meditations on Memoir and

Education (Alison Pryer)]. Paideusis, 20(2), 57-59.

https://doi.org/10.7202/1071831ar

This document is protected by copyright law. Use of the services of Erudit (including reproduction) is subject to its terms and conditions, which can be viewed online.

https://apropos.erudit.org/en/users/policy-on-use/ 
Paideusis, Volume 20 (2012), No. 2, pp. 57-58

Review of

\title{
Embodied Wisdom: Meditations on Memoir and Education
}

by Alison Pryer, Charlotte: Information Age Publishing, 2011.

\author{
BARBARA BICKEL \\ Southern Illinois University Carbondale
}

This book unfolds within liminal space - between nondual and dual, east and west, personal and professional, home and school, imagined and real. Alison Pryer has written a book that is vulnerable. Yet it is a strong inquiry into a contemplative life of teaching and learning that takes place in the hidden curriculum of her life. In the act of doing this, she reveals the hidden and marginalized curriculum of our western culture and school systems and offers a single mirror reflection of honesty back to it.

She writes with a humble honesty that draws wisdom from weaknesses-from the places and times where she failed to embody her own ideals. The tenacious strength she exhibits in her writing is in the care for self she demonstrates as she reveals her own fear and weakness as a learner and teacher.

Her invitation to the reader asks to find out who they are through witnessing her stories, thus initiating an act of co-poiesis. She writes that, "Witnessing is an active, rather than a passive process in which the reader becomes the co-performer of meaning" (p. 20). Rather than telling the reader how to embody wisdom, she demonstrates the practice herself through a compassionate and critical excavation of her own life experiences. Through embodying her text, she invites the readers alongside her to do likewise.

The entrance into the book is a tracking of her journey from dual to a non-dual pedagogy-in other words, a journey from being a disembodied learner who viewed mind and body as a rigid duality to being an embodied learner and teacher. She walks and reflects upon this journey as an "intellectual liminar" or "nomad"- one who chooses to explore life from the margins rather than the centre. Her understanding of education has a wide embrace and is not limited to traditional school settings. Incorporating a non-dual philosophy of education in which "mind and body and heart are brought together through practice and tradition" (p. 126), she expands the embrace of diversity needed to undermine violence that is too often perpetuated by a rigid dualistic educational paradigm. She explains that this violence is enacted through complex and interwoven institutional rituals (in schools, church and family) that establish and perpetuate violence through "differential, unequal gender relationships" (p. 98). Her embodiment of the intellectual nomad employs a practice of autobiographical memoir writing as a means to step into difficult "truths." Language is employed as craft and as means to delve into the unknown and difficult truths.

Chapter 3 begins with "sensual wisdom" and shares personal and student examples of how love and care can lead us to sadness and the releasing of tears from our body in response to the complex life of a student teacher opening him/herself to others in an authentic way. In this remembering, Pryer

(C) Copyright 2012. Barbara Bickel assigns to Paideusis the right of first publication and educational and non-profit institutions a non-exclusive license to use this document for personal use and in courses of instruction provided that the article is used in full and this copyright statement is reproduced. Any other usage is probibited without the express permission of the author. 
reflects on the importance of "coming to our senses" as beings who are also teacher educators, student teachers and teachers. Coming to our senses leads to exploring the erotics of pedagogy in chapter 4. She writes that "Teaching, learning, and knowing are all erotic acts. Eros is always in movement, always in relation, always incomplete" (p. 42). Her critique of the teachers' and schools' inability to open themselves to the different "other" in their quest for a sanctioned knowledge and desire begins to make itself present. She includes herself in the critique.

The development of Pryer's own hybrid identity is revealed in her exploration of personal family stories in chapter 5; the sanctioned, forgotten and hidden stories. The complexity of family lines and the formation of a familial identity are questioned with curiosity and acceptance of what has been gained and lost. She performs a critical personal ethnography into her family's historical stories that bring "historical truth" into question. The differing family stories she uncovers are embedded and formed within a relationally conflicted Irish and English history. Her personal inquiry consequently also serves to offer an important cultural ethnography. Chapter 6 offers a resting place in the book, in which Pryer discusses the possibility of a healing space through ritual. I appreciate Pryer's simple rendering of ritual, which reminds us of the simplicity and power of ritualizing that is present in our lives individually and communally as sites for reflection and learning, returning and restoring.

In reading chapter 7 on remembering and silencing, I was impressed by the wisdom and clarity of her exhortation to break the silence regarding violence in our homes and our schools, and I found myself questioning my neglect in failing to offer student teachers in my own classes an opportunity to explore how better to deal with the trauma of child abuse enacted and perpetuated in schools. Pryer's inquiry reveals how schools and teacher education programs continue to avoid educating teachers and parents about childhood sexual abuse. Instead, schools rely on the victimized child to disclose their abuse, a passive strategy does not take into account the amplified fear that a victim of child abuse will have of adults. She ends this challenging chapter with a vision for a poetics of peace that utilizes the essential liminal practice of the arts as a means to break open what is repressed and avoided.

In chapter 8 , Pryer shifts into a discussion of hockey that surprised me initially, but which became a playful way to transition from the chapter on violence into how culture sanctions and glorifies violence through the art of sports. She leaves us with important questions to ponder in regard to national sports and gendered cultural roles.

Her final memoir chapter develops the artistic practice of an embodied pedagogy of the heart. In this chapter, Pryer exposes herself and her own cultural biases in her account of her experience of studying Ikebana [art of flower arranging] in Japan with a master teacher and community of learners. Learning to be open to the simple moments of teaching and learning and to the mystery of our unfolding through gentle yet critical contemplation is the embodied wisdom that Pryer imparts in her book.

Through her willingness to reveal and to reflect upon her own life experiences with a gentle, almost spontaneous discipline, Pryer makes possible the exposure of secrets in our lives and schools that can then lead to questioning and transformation. Her book is worthwhile reading for anyone committed to creating an ethical and compassionate embodied non-dual learning and teaching paradigm in a culture that is losing its ability to see or act outside of the duality of its practices.

\section{References}

Ettinger, B. L. (2005). Copoiesis. Ephemera: Theory and Politics in Organization, 5(X), 703-713. 


\footnotetext{
i Artist theorist Bracha Ettinger defines copoiesis as the "aesthetical and ethical creative potentiality of borderlinking and of metramorphic weaving" (Ettinger, 2005, p. 705). It occurs through intimate encounters between several others linking across borders of difference to co-create something new.
} 